\title{
Digital Technologies in Early Childhood: Attitudes and Practices of Parents and Teachers in Kosovo
}

\section{Majlinda Gjelaj}

Asst. Prof., Faculty of Ed., University of Prishtina, Kosovo, majlinda.gjelaj@uni-pr.edu

\section{Kastriot Buza}

Assoc. Prof., corresponding author, Faculty of Education., University of Prishtina, Kosovo, kastriot.buza@uni-pr.edu

\section{Kyvete Shatri}

Asst. Prof., Faculty of Ed., University of Prishtina, Kosovo, kyvete.shatri@uni-pr.edu

\section{Naser Zabeli}

Assoc. Prof., Faculty of Ed., University of Prishtina, Kosovo, naser.zabeli@ uni-pr.edu

The purpose of this study was to examine preschool teachers and parents' attitudes and their practices regarding the use of digital technologies during preschool education. The main research questions the study intended to address focused on teachers' and parents' attitudes and practices about the role of digital technology supplies in young children's development. The study used a mixed research approach, using in-depth interviews and an online questionnaire. The results have shown that only one of the eight preschool teachers reported a positive attitude regarding the impact of digital technology in children's development. Most of the interviewed preschool teachers showed preference towards authentic play and activities exercising children's psycho-motor skills. However, most of parents have suggested that their children, starting from early years of their development, are exposed to different digital technologies. In conclusion, there are two contradictory findings (progressive and regressive philosophies) among parents and preschool teachers regarding their perceptions and practices on the use of digital technologies in young children's learning and development. The study advocates for continuous cooperation between parents and teachers to ensure prospects of maximizing benefits and alleviating potential risks of using digital technologies in early childhood education.

Keywords: preschool teacher, parents, digital technology, attitudes, practices

Citation: Gjelaj, M., Buza, K., Shatri, K., \& Zabeli, N. (2020). Digital Technologies in Early Childhood: Attitudes and Practices of Parents and Teachers in Kosovo. International Journal of Instruction, 13(1), 165-184. https://doi.org/10.29333/iji.2020.13111a 


\section{INTRODUCTION}

Technology plays a crucial role in children and adults' everyday lives. There are numerous studies showing that the use of digital technology, from different user groups, is increasing every day. However, studies also show that there are different perceptions regarding the advantages and disadvantages of the use of digital technology children, especially during their early ages of development.

Information and Communications Technology (hereafter ICT) can be defined as "anything which allows us to get information, to communicate with each other, or to have an effect on the environment using electronic or digital equipment" (Bolstad, 2004) However, according to Kalas (2010), in early childhood education literature (hereafter ECE), the concept of ICT includes computer hardware and software, digital cameras and video cameras, the Internet, telecommunication tools, programmable toys, and many other devices and resources.

In many countries, ECE or preschool education is conceptualized differently. This study focuses on preschool education, i.e. the years before children attend elementary school. In Kosovo, the Law on Pre-university education requires children to enrol in elementary school at six years old. Therefore, the study concentrates on perceptions on the use of technology during children development before the age of six, known as preschool age as defined by the Kosovo Curriculum Framework (MEST, 2016). In addition, the study focuses on the use of digital technology at early childhood institutions and their home. Early childhood education policies and practice itself in Kosovo has been a great challenge for the overall educational policies. According to a study report published by the "Kosovo Education and Employment Network - KEEN" project, the inclusion of children in institutionalized pre-school education in Kosovo continues to be a challenge given that by 2017, according to data from the Education Management information System (EMIS), there are only 42 public kindergartens and 88 licensed private institutions, 5 which are community-based (Gjelaj, Rraci \& Bajrami, 2018). As a result, Kosovo remains the country with the lowest inclusion of children in preschool education, aged 0 to 4 years old, in the region, with an inclusion rate of $4.5 \%$. The highest inclusion rate is in pre-primary classes (aged 5 to 6 ), where $76.27 \%$ of children are involved (Ibid).

Despite this current situation the Kosovo Education Strategic Plan (KESP), (2017-2021) under the strategic objective 'teaching and learning', plans to maximize learning through quality teaching, implementing competency-based curricula, and by using high-quality teaching resources. The implementation of the new curriculum in all schools is understood as central to improving the quality of learning in Kosovo. In addition to teacher training, this requires the preparation of textbooks and other teaching and learning materials, including electronic teaching materials that are in harmony with the Kosovo Curriculum Framework (KCF). This also assumes that special attention should be paid to providing schools with ICT equipment, as well as other teaching support.

However, two important stakeholders in early childhood development, teachers and parents, have opposing opinions regarding the use of digital technology in education. 
The purpose of this study is to analyze teacher and parents' attitudes and practices about the use of digital technologies during early years of education. The study aims to give answer to two main research questions:

1. What are the attitudes and practices of the parents towards the use of digital technology during early years of children development at home?

2. What are the attitudes and practices of preschool teachers toward the use of digital technology during early years of children development in kindergarten education?

\section{LITERATURE REVIEW}

Historically, theorists and researchers have debated whether young children should use technology at school (Alper, 2011; Blackwell, 2013; Cordes \& Miller, 2000; Kirkorian, Wartella, \& Anderson, 2008; House, 2012; Lindahl \& Folkesson, 2012; Morgan, 2010, Parett, Quesenberry \& Blum, 2010; Plowman \& McPake, 2013 at Zomer and Kay, 2016). Various authors have expressed the view that computer/ICT use is not appropriate for young children's cognitive, physical, social, and emotional development. However, there is no clear evidence to support this claim, and this view has increasingly been replaced by the view that, when used appropriately, ICT can be a useful tool for supporting young children's learning and development (Bolstad, 2004). There are diverse attitudes presented from different stakeholders when discussing early years of children development and the use of digital technology.

Today, it is common to observe toddlers and preschool children watching videos, playing games on tablets, or exploring on the internet. With such dynamic developments, there is a need to establish a better understanding of the process of engaging ICT in everyday play and learning activities of preschool children. Several recent research findings pointed out the extraordinary potential of ICT to enhance the learning and other developmental processes of children (Kalas, 2013). According to Kalas (2013), studies have shown that digital technologies can provide children with new opportunities to engage in attractive and relevant play, learning, communication, exploration, and development. Properly integrated digital tools can empower younger children by providing them with a voice, especially with limited literacy capabilities, at their young age (U.S. Department of Education, 2016). Digital technologies as digital toys which are properly integrated in learning can empower children by granting them a voice they have never had before. In this context, digital technologies also open new pathways for alternative social interactions and change the learning relationships between children and teachers (UNESCO, 2012).

Hayes and Whitbread (2006) examined a holistic development of young children's learning and identified seven different ways that learning could be enhanced by integrating ICT, namely, (a) ICT and literacy; (b) ICT and mathematical understanding; (c) ICT and science; (d) creativity, problem solving, and playful use of technology; (e) visual literacy and painting; (f) media education (digital animation); and (g) learning of music. Results of the interviews with teachers and parents as shown by the study of Ihmeideh \& Alkhawaldeh (2017) have indicated a clear perpetuation of the role of 
technology and digital media in the intellectual, religious, and moral aspects due to the contributions of these aspects to children's learning and development. Based on Byron (2008), New Zealand Council for Educational Research (2004), and Stephen \& Plowman (2002), most of the concerns fall into one of four categories: (a) harmful physical effects; (b) children's learning, cognitive, social, and emotional development; (c) exposure to harmful contents; and (d) new technologies displacing other important learning and play activities. However, nowadays, it is almost impossible to come across an educational institution without an ICT presence.

In early childhood education, the term ICTs could include computers digital cameras and digital video cameras, creativity and communication software and tools, the internet, telephones, mobile telephones, tape recorders, interactive stories, computer games, programmable toys, videoconferencing technologies and closed-circuit television, data projectors, microphones, headphones electronic whiteboards and more (Olowe \& Kutelu, 2014). Early childhood in-service and pre-service teachers' views are essential for ICT integration in early childhood settings and studies have shown that positive views are crucial for influencing their decisions to use ICT in their teaching (Sime \& Priestley, 2005). Their views and intentions predict the integration (or lack thereof) of ICT in the classroom, while the successful integration will also depend on other factors such as appropriate skills and training (Sime \& Priestley, 2005). Inan \& Lowther (2009) examined the effects of teachers' individual characteristics and perceptions of contextual factors that influence ICT integration in classrooms. One of the independent variables included in their study was teachers' beliefs about technology, which was defined as the teachers' perception of the influence of technology on teaching and learning practices. Findings showed that teachers' computer proficiency, teachers' overall support, teachers' technical support, and computer availability have a significant influence on teachers' beliefs about technology. Also, teachers' beliefs had a strong influence on the use and integration of ICT in classrooms.

Regarding pre-service early childhood teachers, Angeli (2004) showed that they are not free of personal beliefs about the role of ICT in early childhood settings and that they may also have misconceptions about the potential of ICT tools in teaching and learning. Although they appropriate technology in their role as students (e.g., to prepare lessons plans), they resist seeing technology as a part of their relationship with children and express little desire to use computers with children, as future teachers (Laffey, 2004). Furthermore, Kiridis, Tsakiridou, Kaskalis, \& Golia (2004) have found that pre-service early childhood teachers have positive views about the use of computer in early childhood settings. Such views have pointed out that the use of computer enhances teaching, thus, computers should be used across all kindergarten activities. Their findings have recommended the introduction and use of computers have positive outcomes for young children, such as: higher concentration and participation in educational process, enhancement of learning outcomes, and facilitation of communication.

Literature also speaks that in-service teacher training has been of informative nature and non-systematic (Minaidi \& Hlapanis, 2005) and relevant courses mainly aim at the 
development of teachers' familiarity with ICT (use of word processing, spreadsheet, presentation programs and internet). According to Gialamas \& Nikolopoulou (2010), the positive influence of the computer self-efficacy on views-intentions is statistically significant for each population, but it is stronger for the teachers. This finding is in agreement with earlier studies that showed positive relationships between computers self-efficacy and in/pre-service early childhood teachers' views (Chen \& Chang, 2006; Tsitouridou \& Vryzas, 2001, 2004).

On the contrary to teacher' perceptions and beliefs, parents are more opened to use different supplies of digital technologies and most of studies show that there is a strong relationship between parent's different habits and influence to their children. Studies show that nowadays parents are not spending much quality time with their children while the amount of time spent by them on reading to their children is very low (Shin, 2015; Hesketh, Hinkley \& Campbell, 2012). Studies also found that parent technology use or attitudes toward media to be positively correlated with their children's use of technology. Further analyses indicate that child screen time use appears to be the result of an interaction between child and parent factors and is highly influenced by parental attitudes (Genc, 2014; McCloskey et al. 2018; Vittrup, Snider, Rose \& Rippy, 2014; Blackwell, Lauricella \& Wartella, 2014). Overall, parents showed positive attitudes toward media, to the extent that they believed media exposure to be vital to children's development, and many disagreed with recommendations from expert sources regarding age-appropriate screen time (Vittrup, et al. 2014).

\section{STUDY CONTEXT}

The Republic of Kosovo is the newest state in Europe. It declared its independence on February $17^{\text {th }}, 2008$. The total population of the Republic of Kosovo is estimated at 1.8 2.2 million, with ethnic Albanians comprising 88\%, ethnic Serbs 7\% and other ethnic groups $5 \%$ of the total population.

The current education sector in Republic of Kosovo is undergoing extensive reform efforts in all sub-sectors, addressing key challenges of increasing participation and improving equity and quality of education with limited resources. According to the Strategic Developing Plan of Education (2017-2022), despite good progress in education reform, there are challenges to be addressed. Regarding preschool education system, Kosovo seems to have the lowest rate of inclusion of preschool children in institutionalized education. According to the Agency of Statistics in Kosovo (2017), there are only 42 public kindergartens in overall state. The capital of Kosovo, Prishtina municipality has started implementing new model of community-based kindergartens and it seems the best way to expand the inclusion of preschool aged children in education.

The National Development Strategy Plan (2016-2021) aims at improving the quality of education and early childhood education is one of the priorities. The new Kosovo Curriculum Framework (KCF) focuses on learner-centeredness, competencies, integrated teaching and learning, flexibility, mobility and transparency (MEST, 2016).

Overall, Kosovo is considered to have a very advanced legislation in the field of education (pre-primary education for children aged 5-6 years is expected to become 
mandatory after a financial analysis done by 2015 (KOMF, 2014). Public awareness about the importance of ECE has also risen due to initiatives of UNICEF, MEST, and numerous partner organizations. MEST has committed itself to providing improved access and quality education for all children and on all educational levels including Early Childhood Education (ECE). Preschool education is now part of the wider PreUniversity Strategy. During 2008, preschool sector started to acquire support by MEST in order to develop Early Learning Development Standards (ELDS) for children from birth to 6-year-old. The goal of the Early Learning Development Standards was to increase the quality of education activities in preschool education both in the family environment and preschool institutions (MEST, 2011).

However, the Kosovo Education Strategic Plan-KESP (2017-2021) and the document of Kosovo Curriculum Framework underline that in order to become successfully integrated into a digital economy, students need to attain digital competencies. Therefore, along with basic knowledge of literacy and numeracy, the current and future education system should stress the importance of digital awareness and literacy, so that full functional literacy is achieved during formal schooling (MEST, Kosovo Education Framework, 2016). Even though educational policies in our country prioritize the continuous professional development of educators and the integration of ICT at all levels of pre-university education and specifically in preschool institutions. This research contributes to enhancing the aspect of cooperation between educators and parents in harmony with Kosovo's strategies and documents for Digital Technologies in Early Childhood.

\section{METHOD}

\section{Participants}

The sample for this study includes 8 preschool teachers selected randomly from 7 public preschool institutions all over Kosovo in order to see if there are differences in perceptions regarding the use of digital technologies in early childhood education between preschool teachers working in different parts of Kosovo. The number of kindergartens in the cities of Kosovo is very low, (usually there is one kindergarten in one city). However, the situation regarding the availability of kindergartens (public, private, and community based) is higher in Prishtina, the capital of Kosovo. Teachers involved in this study varied also in terms of age and working experience.

Table 1

Teachers' Demographic Characteristics

\begin{tabular}{llllllll}
\hline Variable & Gender & Ethnicity & Age & $\begin{array}{l}\text { Working } \\
\text { experience }\end{array}$ & Education & $\begin{array}{l}\text { Working } \\
\text { place }\end{array}$ & $\begin{array}{l}\text { Type of } \\
\text { kindergarten }\end{array}$ \\
\hline Teacher 1 & $\mathrm{F}$ & Albanian & 59 & 37 & Pedagogical High School & Peja & Public \\
Teacher 2 & $\mathrm{F}$ & Albanian & 45 & 19 & Faculty of general pedagogy & Prishtina & Public \\
Teacher 3 & $\mathrm{F}$ & Albanian & 51 & 26 & Pedagogical High School & Gjakova & Public \\
Teacher 4 & $\mathrm{F}$ & Albanian & 30 & 7 & Faculty of Education (BA) & Prishtina & Public \\
Teacher 5 & $\mathrm{F}$ & Albanian & 42 & 18 & Faculty of Education (BA) & Ferizaj & Public \\
Teacher 6 & $\mathrm{F}$ & Albanian & 50 & 25 & Pedagogical High School & Podujeva & Public \\
Teacher 7 & $\mathrm{F}$ & Albanian & 41 & 18 & Faculty of Education (BA) & Gjilan & Public \\
Teacher 8 & $\mathrm{F}$ & Albanian & 45 & 17 & Faculty of Education (BA) & Prizren & Public \\
\hline Mean & \multicolumn{70}{c}{45.3} & 20.8 & & & \\
\hline
\end{tabular}


In addition to preschool teacher attitudes, also parents 100 randomly selected parents participated in the study. Table 2 provides parent demographic information.

According to Creswell (2014), one of the most common probability sampling approaches used by researchers is random sampling, which allow representatives (preschool teachers and parents in this study) an equal chance of getting selected. This sampling strategy was purposely chosen by our group of researchers, considering that topics such as the use of digital technologies in early childhood education are limited in the context of developing countries, such as Kosovo. Hence, this sampling strategy allowed our study to acquire a wide range of perceptions from both preschool teachers and parents as randomly selected the selected sample representatives, enhancing the value of our findings.

Table 2

Parents' Demographic Characteristics

\begin{tabular}{llll}
\hline Children age & N & \multicolumn{2}{l}{ Place of living } \\
\hline $0-1$ & 11 & Rural & Urban \\
$2-3$ & 28 & $10 \%$ & $90 \%$ \\
$4-6$ & 52 & & \\
Didn't declare & 9 & & \\
\hline \multicolumn{4}{l}{100 -total } \\
\hline
\end{tabular}

\section{Instruments}

The study used both in-depth interviews and an online questionnaire to collect the data.

In depth interviews with 8 preschool teachers where used to find out what are the teacher attitudes and practices regarding use of digital supplies in preschool education settings. A model of in-depth interview protocol used from Kelly (2014) was used to identify four dimensions of teacher attitudes toward use of digital technology, consisted from:

1.Teacher previous experience with regards to technology use,

2.Availability of digital technologies in current workplace,

3.Own believes about technology effects to children learning and development, and

4.Professional development activities with regard to technology skills

Questions about the practices of integration of technology during the classes and the ones that ask to describe the lessons/ activities with technology where avoided when teachers declared that they do not have any kind of digital technology in their classrooms.

In order to collect preschool parents' attitudes regarding the use of use of digital technologies in early childhood education, an open online questionnaire was distributed to 100 parents in October, 2017.

The questionnaire was self-constructed and adjusted to the context. It covered main research questions dealing with parental attitudes and practices about:

- $\quad$ The types of digital technologies used by their children 
- $\quad$ The amount of time spent with any kind of digital technologies, and - Believes about advantages and disadvantages regarding the effects of digital technologies on their children development and school readiness.

\section{Data Analysis}

The in-depth interviews were analyzed using content analysis (Kolbe \& Burnett, 1991). In addition, the four dimensions from Kelly (2014) model were used as criteria and guiding elements to convey many themes and discussions. The content analysis was followed by a descriptive statistical analysis of the online questionnaire (Creswell, 2014).

\section{FINDINGS}

\section{Parents Attitudes and Practices about use of Digital Technology during Early} Years

According to the data, parents' attitudes and practices about use of digital technology during early years can be organized into two groups. One of the groups comprises parents that support the idea of enabling their children to use digital technologies, such as TV, laptop, tablets, smart devices, computers, gaming technology (see Fig 1). The other group of parents represents the opinion of avoiding their children's exposure to digital technologies during their early stages of development (see Fig. 5)

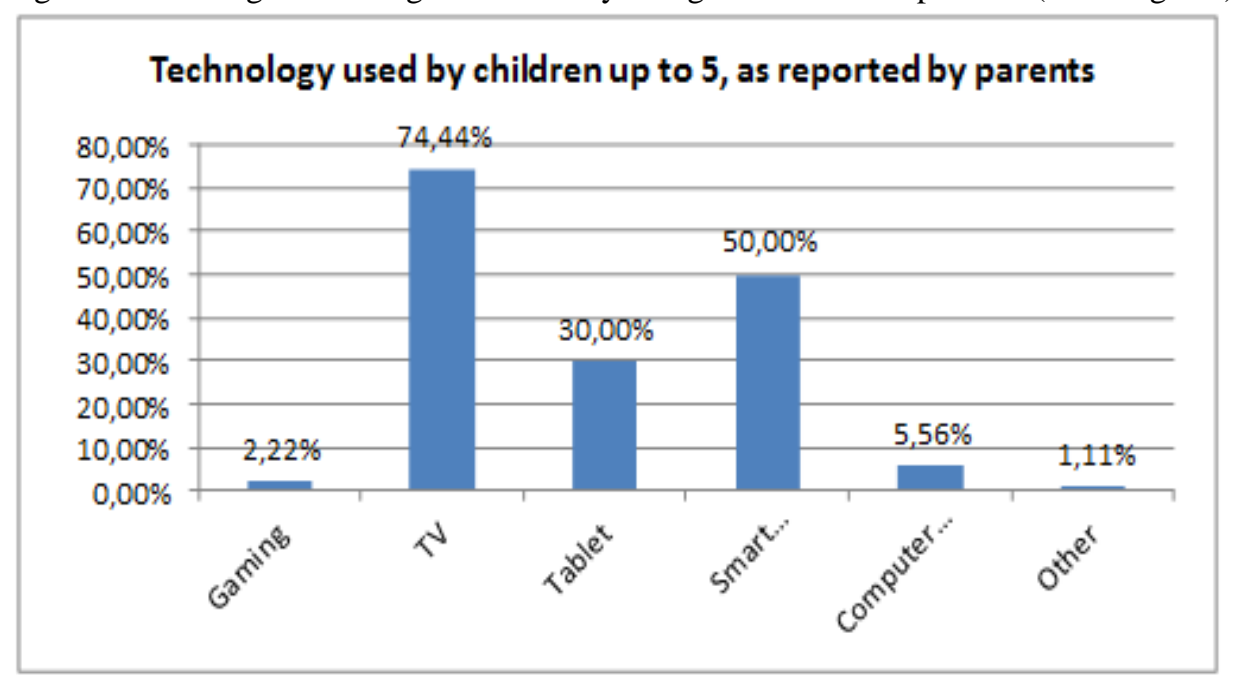

Figure 1

Type of Technology Used by Children up to 5, as Reported by Parents

The questionnaire data showed that most of the parents $(66.67 \%)$ declared positive towards the use of digital technologies for their young children (ages 0 to 5). The results presented have indicated that most of parents grant access to TV (74.44\%), smart phones $(50.50 \%)$, and tablets $(30.00 \%)$ for their young children (ages 0 to 5). Parents 
reported that they are satisfied with how their young children access and use technology at home, referring to the benefits of technology use, including but not limited to a) learning of English language, b) acquiring technology skills, and c) general development. In fact, around 43 percent of parents declared they are firm believers that children using technology will promote their school readiness. However, around 57 percent of them do not support this relationship.

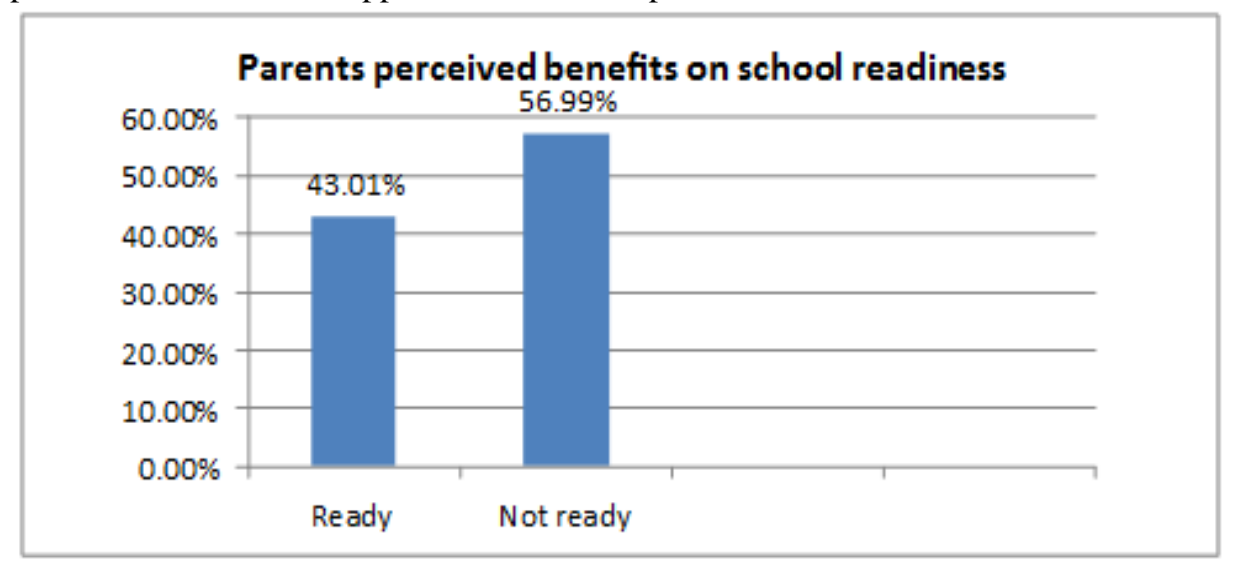

Figure 2

Parents Perceived Benefits on School Readiness

Despite the countless benefits, parents associate technology use with socializing problems, too much screen time, sleeping problems, physical development delays while they also think that children miss outdoor play with their peers and they even develop behavioral problems from the contact with inappropriate content such as violence and aggressive games.

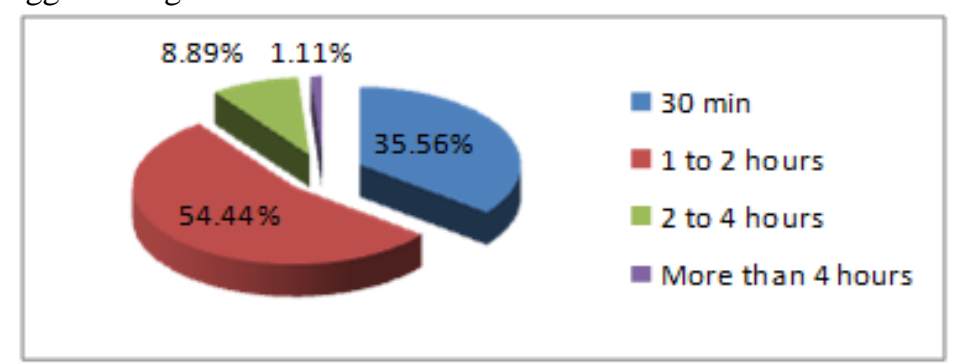

Figure 3

Time Children Spend Using Technology Each Day

The data presented in the pie chart above indicates a variation of children's time allotted in front of screen, from 30 minutes to 4 hours per day, as reported by parents. Most of the children (54.44\%) use any type of technologies up to 2 hours per day. According to Lauricella, Wartella \& Rideout (2015), there is scientific evidence to argue that very young children spend less time with media than older children. This finding corresponds 
with other findings (Lauricella, Wartella \& Rideout, 2015), suggesting the general assumption that there is less exposure to technology in educating very young children.

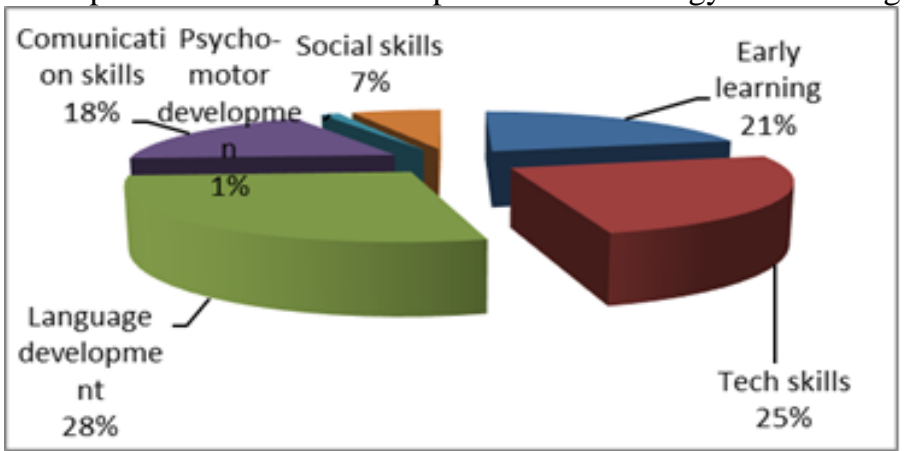

Figure 4

Parents' Perceived Benefits Associated with Technology Use

While there is evidence to suggest that the use of technology does not nearly support children's social skills development, it is important to recognize that parents are aware of the benefits technology brings. The questionnaire results showed that parents believe that by using digital technologies, children improve their language skills (46.15\%), early learning skills $(35.16 \%)$, and technology skills $(40.66 \%)$. Having in mind that there are very few applications for young children in Albanian language (main language in Kosovo), children are using digital platforms in English language and this might be considered by their parents as e beneficial modality for their children language development. These results complement other studies related to the language teaching lessons in particular. Such studies emphasize that the use digital stories that promote lessons as enjoyable and productive affect the improvement of language skills, interest, attitudes, attention and motivation in a positive way (Girmen \& Kaya, 2018). However other fields of development are considered to be rather poorly developed, such as social skills (10.99\%), psycho- motor development (2.20\%), and communication skills (29.67\%).

In addition, our findings of this study are consistent with other studies in the field of early childhood education and the use of technology. Such studies also support the conclusion that parents have positive attitude towards the use of digital technologies in early childhood education (see: McCloskey, 2018; Genc, 2014; Vittrup, 2014; Blackwell, Lauricella \& Wartella, 2014). In addition, they support the process of exposing their children to technology supplies arguing in favor of the technology benefits on their children development. As reported by Ihmeideh \& Alkhawaldeh (2017), both parents and teachers expressed a high degree of agreement concerning the role of technology digital media in developing child culture.

Nevertheless, data presented in the Figure 5 indicates parents' concerns about the negative effects of technology on their children's development. As our findings present, parents' indicate their concerns by reporting distress that their children: a) are spending excessive screen time $(51.55 \%)$, b) can be exposed to inappropriate content when using 
the internet $(40.21 \%)$, c) engaged in less active play time $(58.76 \%)$, d) might be negatively influenced by commercial content $(11.34 \%)$, e) are engaged in less time playing in the yard $(51.55 \%)$, might develop physical disorders $(36.08 \%)$, and f) might develop sleeping problems $(28.87 \%)$. In such cases, while studies (see: Girmen \& Kaya, 2019; McCloskey, 2018; Genc, 2014; Vittrup, 2014; Blackwell, Lauricella \& Wartella, 2014) highlight the importance of the use of digital technologies in early children's education, our study points towards other imperative aspects in early children education that might lack behind due to the use of technology.

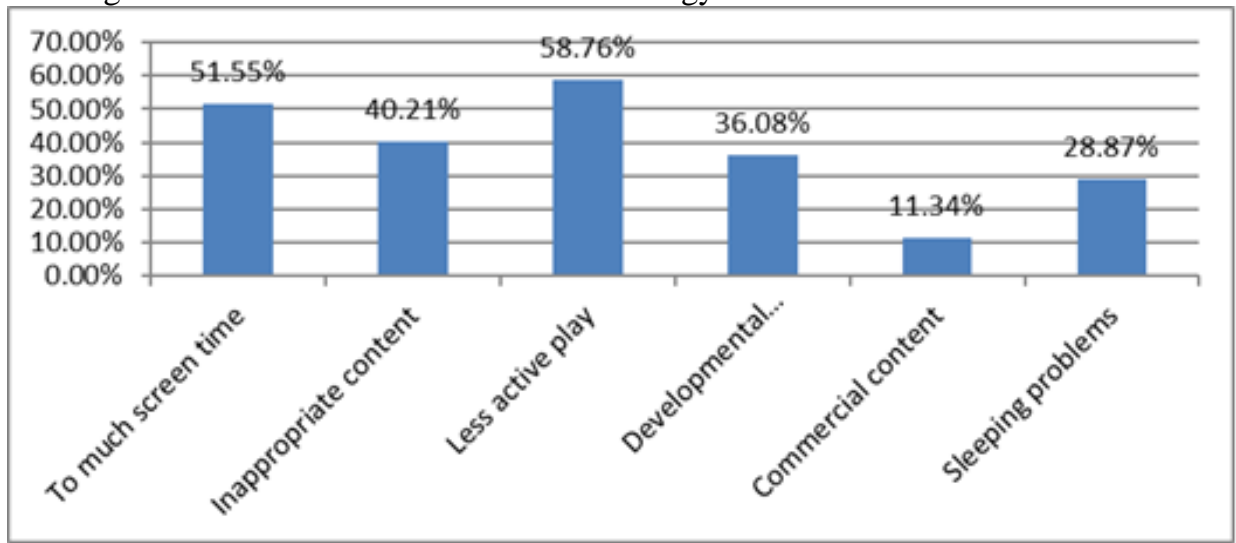

Figure 5

Parent's Concerns About Negative Effects from Digital Technology Use

\section{Preschool Teachers Attitudes and Practices about use of Digital Technology during Early Years}

Comparing to parents' attitudes, preschool teachers declared themselves very differently regarding the use of digital supplies during early year's education. Most of the teachers believe that young children, during this age, mostly need interaction with their surrounding environment and engage with concrete tools (toys).

\section{Teacher experiences with regards to technology}

As declared by the interviewed teachers, most of them have been raised and educated in an environment without the use of any type of digital technologies. None of them were provided with the opportunity to be exposed to an education environment that makes uses of digital technologies available at their disposal for teaching and learning. Their education system did not support any digital technology learning tools. The interview results emphasized that the previous education system power students learning through making use of physical materials as means of demonstration. Back then, the only technology related supplies that students were acquainted with were radio and TV. Therefore, teachers' lack of experience with technology related supplies during their previous learning experience is a valid predictor for their current attitudes and perceptions regarding the use of technology in early childhood education. The following verbatim quote represents this same argument. 
"Our teachers never used technology in the classroom. We were educated in a very traditional method. We didn't have computers in school or at home. We even didn't have TV at school. The main source of knowledge was books and teachers. During early childhood we didn't used to go to kindergarten. We went to school for the first time when we were 7 years old. I saw a computer for the first time on 1999, when we bought one for my son" declares a preschool teacher (L.M, age 59).

It can be seen also from other interviewed teachers that their experience with regard to technology was very poor. The presented lack of experience could have affected teachers believes, attitudes, and practices on their present work with young children. Only one from eight teachers declared that she was trained to work with computer.

\section{Available technology supplies in current working place}

Most of the teachers declared that they have only one TV in the kindergarten. The TV is placed in a joined room where all the children from different groups could have their time to go there and watch a movie. During the previous years, they were asked or advised from the educational inspectors not to let children watch TV at all, since they are being passive during that time. Based on their experience, they were using TV only for calming down the children as they prefer watching TV. This indicated experience shows that the only technology available in the kindergarten was no used for educational proposes. Five from eight kindergartens reported that they only possessed one videoprojector that is rarely used, since the group is packed and it is logistically inconvenient to organize spate projector group uses. Moreover, the interviewed teachers declared that they lack any kind of smart devices in the classroom. In addition, children are not allowed to bring their own devices at school/ kindergarten. In all the classrooms, they declared that they do have a music player. The music player is bought usually by parents. There are no computers in the classrooms in none of the seven public kindergartens in Kosovo's main cities.

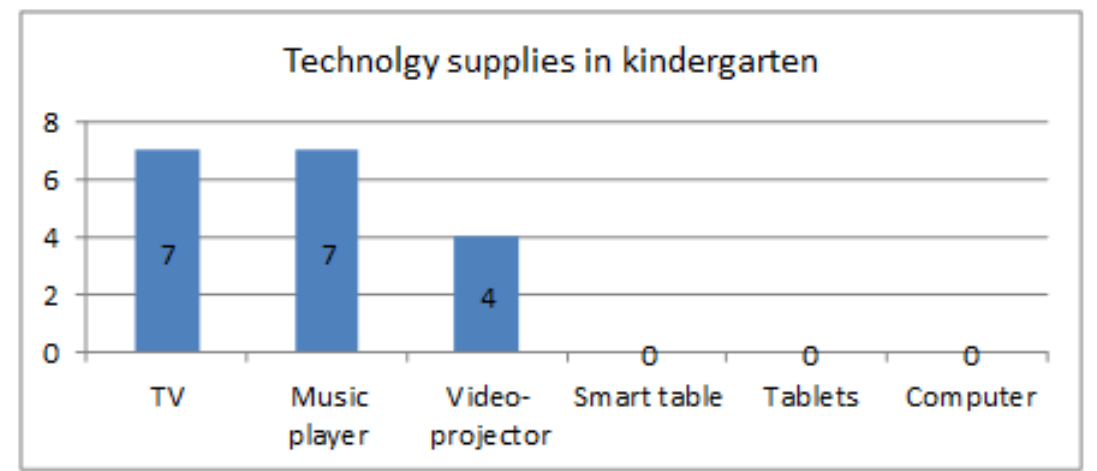

Figure 6

Type of digital technology supplies in the kindergarten as declared by teachers

Instead of real digital technology supplies, preschool teachers declared that they use technology supplies brought by parents such as: TV, microwave, iron, radio, which are 
not properly functioning or are out of order. A preschool teacher has reported the following:

"Through imaginary play with these technology supplies, children develop their communication skills and creativity, as well as enjoy role playing” (I.G, age 41).

A preschool teacher working in a public kindergarten (F.H. age 45) declared that:

"We encourage children to play in groups, socialize with each- other through authentic play and toys, even if they want to bring their own smart devices, we don't allow them to do so because the devices are fragile and children can break them and we don't have time to deal with such issues"

\section{Personal attitudes towards digital technology}

There is a consensus among the majority of the interviewed teachers that using digital technology during early years will only harm children psycho-physical development. The results have shown that they ignore any possibility that the use of technology devices is beneficial during early childhood education. Teachers have claimed that if kindergarten funding would enable them to purchase technology supplies, they would only utilize them as didactical materials, serving as means for providing illustration and examples. Such technology supplies will not to be used by children themselves.

Most of the kindergarten teachers (seven from eight) believe that children already spend a lot of time using digital devices at home so while they are at school or kindergarten, they should only play and learn in interaction with the environment, other children, and other adults.

"Children learn best when they explore and discuss with their peers and adults. They need to move around, solve authentic problems, think critically and resolve possible conflicts from the real-life experiences" (Preschool teacher H.M. age 51).

One of the interviewed teachers (J.M. age 30) declared that she would use smart devices such as smart boards or other smart tablets. She said:

"We miss very essential materials, toys and paper. I don't know when we will be able to have smart devices in the classroom. We could only ask from parents to bring their own devices at school. Children love exploring and playing with them. They can learn math, language or singing."

\section{Professional development activities for technology skills}

Preschool teachers were asked about their types of professional development activities that have helped them acquire technology skills and to what extent did their college coursework prompted them to integrate technology in classroom. Teachers that have been recently graduated with a bachelor degree in preschool education (Faculty of Education) declared that they had only one course dedicated to ICT in preschool education. The other teachers that have been studying in so called Pedagogical High School (training offered for kindergarten teacher before preschool education was offered at University level) they never had a single course that dealt with the integration of 
technology in teaching. Similarly, teachers coming from the faculty of general pedagogy were not offered any course during their pre-service teacher training. All of interviewed teachers declared that they attended an in-service training of basic ECDL (European Computer Driving License) qualification. However, they have never used such training into their practice due to lack of computers at their disposal at kindergartens where they work.

"It is usually one computer at principal's office, but none in our classrooms" (I.M. age 30).

None of the interviewed teachers feel they are sufficiently prepared to teach early childhood content using technology.

All of them would prefer a training that would prepare them to use different technology supplies and also help them change their traditional mindset toward technology use during early years.

"We admit that the world has changed. Children of today are children of technology era. They like it and maybe they can learn from it if used properly", declares one of the interviewed teachers (I.M. age 30).

The findings supported by this study conclude that younger generation teachers that have been qualified during recent years have been displayed a more open attitude towards the use of technology use and the need to incorporate technology training during their professional development plan. However, teachers who have been educated during pre-professional age (Hargreaves, 2000) have the tendency to be more reluctant to new teaching methods and changing their perspectives.

\section{DISCUSSION AND CONCLUSION}

The purpose of this study was to analyze preschool teachers and parents' views and practices regarding use of digital technologies during early childhood education. Our findings have indicated that there are differences between parents and teacher views and attitudes regarding the use of digital technologies during early years of children or pupil development. Most of the parents of children 0 to 5 declared that they provide to their children different types of digital technology supplies starting from their first year of their development. Regularly, children spend a lot of time on TV, laptop, and other smart technological devices. Children spend screen time from 30 minutes up to more than four hours per day. Parents believe that there are some benefits emerging from the digital media. They believe that their children development increases in some of their developmental areas including: language development, cognitive, early learning skills, and technology skills. Children are using digital supplies in English language and this might be considered by their parents as e beneficial to their language skills development. This funding is consistent with other findings in the field of technology use in early children education (see: see: Girmen \& Kaya, 2018; McCloskey, et al. 2018; Genc, 2014; Vittrup, 2014; Blackwell, Lauricella \& Wartella, 2014), However, while our findings are emerge and support from numerous findings in this field, the novelty of our results should be emphasised. That is, while the use of technology use in early children 
education is important, our study suggests that other fields of development are considered weekly developed, such as social skills, psycho- motor development, and communication skills.

Parents believe that the use of technology improves their children's overall development and school readiness. However, they have also reported some concerns about the negative impact technology might have on their children wellbeing such as: lack of active play time in opened environment, physical development disorders or sleeping problems. Correspondingly, Genc (2014) have showed that parents with negative opinions indicate how smartphone usage can cause physical or mental problems in the future: they fear that their children will be introverted, have an isolated life, or be affected by harmful radiation. Despite this, most of them exposed their children to at least one digital supply during the first year of life and the number of supplies increases on a yearly basis. This finding is very controversial and points toward further discussions in the field of technology use in early children education.

Despite parent's views, preschool teachers have very different attitudes about use of digital technology supplies during early years of children development. The in-depth interviews showed that teacher attitudes are mostly affected by four factors as shown in the model below.

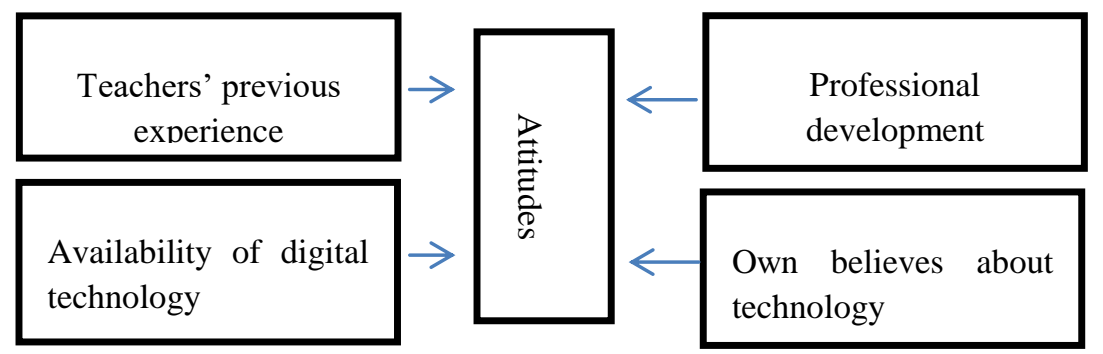

Figure 6

Visualization of Factors Influencing Teacher Attitudes toward Technology Use

Teachers' previous experience with regards to technology use, availability of digital technology supplies in current working place, own believes about technology effects to children learning and development, and professional development activities with regard to technology skills were indicated also very important at Kelly (2014). This study reports that teachers' perceptions were influenced both by the interpersonal level as well as the community/institutional level. In addition, our findings are consistent with Kelly (2014) suggesting that the capacity building of teachers is important for effective use of technology tools.

Teaching experience seems to be correlated to their attitudes toward use of technology. Studies show that teachers with more teaching experience have less favourable attitudes toward technology and use technology less often than teachers with less experience (Blackwell, Lauricella and Wartella, 2014). Our study also depicted a similar situation in Kosovo. Teachers' with more teaching experience where strictly against the integration of technology in their lesson plans or activities with preschool children. Inan 
\& Lowther (2010) showed that teachers' perceptions of instructional benefits are an influential factor that affects technology integration in classrooms. The interviewed teachers in our research also declared their views as negative toward technology. This affected their practice as well. The study of Badia et al. (2014) presents that ICT related school conditions such as ICT teaching policy and ICT infrastructure show a significant but more modest association with teachers' perceived effectiveness of digital technology. Similarly, put finds have reported that the lack of proper technological tools in kindergarten, to a certain extent, have influenced their negative perceptions regarding the use of technology. For many years, these poor conditions have influenced teachers' lack of willing to use technology with young children.

Their professional in service and pre-service development is also poor and their previous experience in school was not guided by the use of technology. As reported by UNICEF (2012), it is imperative that ECCE educators are productively integrated in professional development related to technological use. It is important to understand that the process of becoming ICT competent for ECCE educator is a long-term transformation, which requires continuous support and monitoring. Since its beginning, efficient professional development program must focus both on (a) developing ICT literacy of the educators, and simultaneously utilizing their emerging new literacy for (b) building new pedagogies of ICT in favor of children's learning and development.

Findings of the study are debatable, since, on the one hand the majority of parents support and utilize the use of technology in their children development, while preschool teachers (later in children education) are stemming children's exposure to digital technologies. This influences children development in many levels, while in this case creating two confusing levels of early children education, i.e. using both progressive and regressive philosophies in children development. This is also relevant to initiate discussions at policy level, in the country and other countries concerning with similar conflicts. Findings have policy implications for preschool curriculum implementation towards quality education in early children development. This research contributes to enhancing the aspect of cooperation between educators and parents in harmony with Kosovo's strategies and documents for Digital Technologies in Early Childhood

The question today on the use of technology does not concern the paradigm of whether it is positive or negative. Today, the use of digital technologies in education system is inevitable. Rather, different stakeholders involved with early childhood development should acknowledge both the benefits and risks that technology use brings to children and teachers. A continuous cooperation between parents and teachers should be facilitated to ensure prospects of maximizing its benefits and alleviating potential risks in early childhood education.

\section{REFERENCES}

Alper, M. (2011). Developmentally appropriate new media literacies: Supporting cultural competencies and social skills in early childhood education. Journal of Childhood Literacy, 13(2), 175-196. doi: 10.1177/1468798411430101. 
Angeli, C. (2004). The effects of case-based learning on early childhood pre-service teachers' beliefs about the pedagogical uses of ICT. Journal of Educational Media, 29(2), 139-151. doi: 10.1080/1358165042000253302.

Badiaa, A., Menesesa, J. Sigalésa, C., \& Fàbreguesa, S. (2014). Factors affecting school teachers' perceptions of the instructional benefits of digital technology. Procedia- Social and Behavioral Sciences, 141, 357-362.

Blackwell, C. K., Lauricella, A. R., \& Wartella, E. (2014). Factors influencing digital technology use in early childhood education. Computers \& Education Journal, 77, 8290. doi: 10.1016/j.compedu.2014.04.013.

Bolstad, R. (2004). The role and potential of ICT in early childhood education: A review of New Zealand and international literature. Wellington: Ministry of Education, New Zealand Council for Educational Research.

Byron, T. (2008). Safer children in a digital world: The report of the Byron review. Retrieved from: https://www.iwf.org.uk/sites/default/files/inlinefiles/Safer\%20Children\%20in\%20a\%20Digital\%20World\%20report.pdf.

Chen, J., \& Chang, C. (2006). Using computers in early childhood classrooms: Teachers' attitudes, skills and practices . Journal of Early Childhood Research, 4(2), 169-188. doi: 10.1177/1476718X06063535.

Coalition of NGO-s for Child Protection (KOMF). (2014). Education - An obligation for a visionary state. Komf statment on the involvment of children in pre-primary education. Prishtina. Retrieved from: http://www.childpact.org/wpcontent/uploads/2015/01/Find-KOMFs-full-statement-on-preprimary-education-inKosovo.pdf.

Creswell, J. (2014). Research design: Qualitative, quantitative, and mixed methods approaches. Thousand Oaks, CA: Sage.

Genc, Z. (2014). Parents' perceptions about the mobile technology use of preschool agedchildren. Procedia Social and Behavioral Sciences, 146, 55-60.

Gialamas, V., \& Nikolopoulou, K. (2010). In-service and pre-service early chilhood teachers' views and intentions about ICT use in early childhood setting: a comparative study. Computers and Education, 55(1), 333-341.

Girmen, P., \& Kaya, M. F. (2019). Using the flipped classroom model in the development of basic language skills and enriching activities: Digital stories and games. International Journal of Instruction, 12(1), 555-572. doi: 10.29333/iji.2019.12136a.

Gjelaj, M., Rraci, E., \& Bajrami, K. (2018). Preschool education in Kosovo. Kosovo Education and Employment Network - KEEN" project, 26-27.

Hargreaves, A. (2000). Four ages of professionalism. Teachers and Teaching: Theory and Practice, 6(2), 152-182. doi: 10.1080/713698714.

Hayes, M., \& Whitebread, D. (2006). ICT in the early years. UK: Open University. 
Hesketh, K. D., Hinkley T., \& Campbell, K. J. (2012). Children's physical activity and screen time: qualitative comparison of views of parents of infants and preschool children. International Journal of Behavioral Nutrition and Physical Activity, 9: 152. doi: 10.1186/1479-5868-9-152.

Ihmeideh, F. M., \& Alkhawaldeh, M. F. (2017). Teachers' and parents' perceptions of the role of technology and digital media in developing child culture in the early years. Children and Youth Services Review, 77, 139-146. doi: 10.1016/j.childyouth.2017.04.013.

Inan, F. A., \& Lowther, D. L. (2010). Factors affecting technology integration in K-12 classrooms: A path model. Educational Technology Research and Development, 58(2), 137-154. doi: 10.1007/s11423-009-9132-y.

Kalas, I. (2012), ICTs in early childhood care and education. Russian Federation: UNESCO: http://iite.unesco.org/pics/publications/en/files/3214720.pdf

Kalas, I. (July, 2013). Integration of ICT in early childhood education. Paper presented The X World Conference on Computers in Education, Toruń, Poland.

Kelly, S. A. (2014). Perceptions, beliefs and practices about technology among teachers in a Jamaican infant school (Unpublished doctoral dissertation). University of South Florida, US.

Kiridis, A., Tsakiridou, E., Kaskalis, T., \& Golia, P. (2004). Early childhood education students' attitudes and views abaut the introduction of new technologies in kindergarten, in Florina's pedagogic department. Themes in Education, 5(1-3), 161-172.

Kolbe, R. H., \& Burnett, M. S. (1991). Content-analysis research: an examination of applications with directives for improving research reliability and objectivity. Journal of Consumer Research, 18(2), 243-250.

Kosovo Agency of Statistics (KAS). (2018). Education statistics in Kosovo 2017-2018. Retrieved from: http://ask.rks-gov.net/media/4146/stat-e-arsimir-2017-2018ang.pdf

Laffey, J. (2004). Appropriation, mastery and resistance to technology in early childhood preservice teacher education. Journal of Research and Technology in Education, 36(4) 361-382. doi: 10.1080/15391523.2004.10782420.

Lauricella A. R., Wartella E., \& Rideout, V. J. (2015). Young children's screen time: The complex role of parent and child factors. Journal of Applied Developmental Psychology, 36, 11-17.

McCloskey, M., Johnson, S.L., Benz, C., Thompson, D.A., Chamberlin, B., Clark, L., \& Bellows, L.L. (2018). Parent perceptions of mobile device use among preschool-aged children in rural head start centers. Journal of Nutrition Education and Behavior, 50(1), 83-89. 
Minaidi, A., \& Hlapanis, G. (2005). Pedagogical obstacles in teacher training in information and communication technology. Technology, Pedagogy and Education, 14(2) 241-254. doi: 10.1080/14759390500200204.

Ministry of Education Science and Tecnology (MEST). (2016). Kosovo education strategic plan 2017-2022. Prishtina. Retrieved from: https://masht.rksgov.net/uploads/2017/02/20161006-kesp-2017-2021.pdf.

Ministry of Education Science and Tecnology (MEST). (2016). Kosovo curriculum framework. Retrieved from: http://www.ibe.unesco.org/fileadmin/user_upload/archive/curricula/kosovo/kv_alfw_20 11_eng.pdf.

Ministry of Education Science and Tecnology (MEST). (2011). Kosovo curriculum framework. Retrieved from: https://masht.rks-gov.net/uploads/2015/05/elds-report-albfor-web_1.pdf.

New Zealand Council for Educational Research (2004). The role and potential of ICT in early childhood education. A review of New Zealand and international literature. Wellington. Retrieved from http://www.educationcounts.govt.nz/publications/ict/4983.

Olowe, P. K., \& Kutelu, B. O. (2014). Perceived importance of ICT in preparing early childhood education teachers for the new generation children. International Journal of Evaluation and Research in Education (IJERE), 3(2), 119-124.

Prime Minister of Kosovo. (2016). National development strategy 2016 - 2021 (NDS). Prishtina: Kosovo Government. Retrieved from: http://www.kryeministriks.net/repository/docs/National_Development_Strategy_2016-2021_ENG.pdf.

Shin, W. (2015). Parental socialization of children's internet use: A qualitative approach. New Media and Society, 17, 649-665. doi: 10.1177/1461444813516833.

Sime, D., \& Priestley, M. (2005). Student teachers' first reflections on information and comunications technology and classroom learning: Implications for initial teacher education. Journal of Computer Assisted Learning, 21(2), 130-142. doi: 10.1111/j.1365-2729.2005.00120.x.

Stephen, C., \& Plowman, L. (2002). ICT in pre-school settings: Benign addition or playgroom revolution? Early Childhood Folio, 7, 33-38.

Tsitouridou, M., \& Vryzas, K. (2001). Early childhood education students' attitudes towards information technology. Themes in Education , 2(4), 425-443.

Tsitouridou, M., \& Vryzas, K. (2004). The prospect of integrating ICT into the education of young children: The views of Greek early childhood teachers. European Journal of Teacher Education, 27(1), 29-45. doi: 10.1080/0261976042000211838

U.S. Department of Education (2016), http://sites.ed.gov/oese/2016/04/open-discussionon-the-role-of-education-technologies-in-early-childhood-stem-education/ 
Vittrup, B., Snider, S., Rose, K. K., \& Rippy, J. (2014). Parental perceptions of the role of media and technology in their young children's lives. Journal of Early Childhood Research. 14, 43-54. doi: 10.1177/1476718X14523749.

Zomer, N., \& Kay, R. K. (2016). Technology use in early childhood education: A review of literature. Journal of Educational Informatics, 1, 1-25. 